\title{
Creative Industries in Brazil: Analysis of Specifics Cases for a Country in Development*
}

\author{
Ana Flávia Machado"\#, Bárbara Freitas Paglioto², Tereza Bruzzi de Carvalho \\ ${ }^{1}$ Department of Economics, Federal University of Minas Gerais, Belo Horizonte, Minas Gerais, Brazil \\ ${ }^{2}$ Federal University of Minas Gerais (Knowledge Museum UFMG), Belo Horizonte, Minas Gerais, Brazil \\ ${ }^{3}$ Department of Art Performing, Federal University of Minas Gerais, Belo Horizonte, Minas Gerais, Brazil \\ Email: "anaflaviatavaresmachado@gmail.com
}

How to cite this paper: Machado, A.F., Paglioto, B.F. and de Carvalho, T.B. (2018) Creative Industries in Brazil: Analysis of Specifics Cases for a Country in Development. Theoretical Economics Letters, 8, 1348-1367. $\underline{\text { https://doi.org/10.4236/tel.2018.87087 }}$

Received: January 11, 2018

Accepted: May 20, 2018

Published: May 23, 2018

Copyright (c) 2018 by authors and Scientific Research Publishing Inc. This work is licensed under the Creative Commons Attribution International License (CC BY 4.0).

http://creativecommons.org/licenses/by/4.0/ (c) (i) Open Access

\begin{abstract}
This paper aims to focus in a theoretical approach on the traits of the Brazilian CCIs. They are marked by various forms of inequality, but yet experience a high level of cultural diversity. For this reason, we analyze the sectorial development in respect to the creation of employment, income, emphasizing the actions and policies directed to both segments, through information provided by the Social Information Annual Report (RAIS) ${ }^{1}$ and the Brazilian Association of Digital Game Developers (Abragames). Also using data from the RAIS, we analyze the factors associated with the development of the fashion industry in the major cities. The analysis of these two sectors of the CCIs in a peripheral country sought to put in evidence the institutional differences, different configurations of companies' size, average income, educational level and gender composition. However, those differences disregard spillover potential and cross-fertilization between the fashion and games and apps sectors.
\end{abstract}

\section{Keywords}

Creative Economy, CCIs

\section{Introduction}

The Creative Economy has been recognized ever since the 1990s as a range of sectors, services, products, activities, and arrangements that systematize the combination of three things: culture, creativity and innovation. This articulation has allowed approaching questions related to the economic development,

*Ana Flávia Machado and Bárbara Paglioto Freitas would like to thank FAPEMIG/Conseil Régional NPDC-APQ-03544-15, "Wealth through Sharing - Riquezas Compartilhadas".

${ }^{1}$ The RAIS is a census on the Brazilian formal employment market. It is one of the most important statistical resources on the employment level of the country. 
changing roles of territories in the productive process as well as the social dimension of production, organization and distribution in this New Economy ${ }^{2}$.

The cornerstone of the creative economy is the diversity of practices, products and activities. This diversity mirrors, among other factors, the geographical and social divide of the space where it develops. The relations between the creative economy and regional issues are object of a series of studies that evidence the importance of investigation, guided by the local distinctions [2].

In the case of developing countries, such as Brazil, it is not different, although local distinctions are present. In spite the fact that Brazil has continental dimensions, diverse ethnic groups, providing an incomparable cultural diversity, and the fact it is one of greatest economies in the world and part of the BRICs, there is a series of problems holding back its creative economy. Among them, the disarticulated actions of an industrial policy that concentrates resources in already consolidated sectors, such as automotive industry, oil and civil construction. Also, cultural activities are not given high priority in the distribution of budget resources, having to compete with important areas such as education, health, basic sanitation, among others. To many governmental administrations, culture is still considered superfluous and a luxury, occupying a lesser priority position in the public expenditure. And, when it is chosen to invest in cultural and creative segments, the initiative is restricted to management of extant assets, which fragments and discontinues initiatives. On the other hand, the private sector tends to be dependent on public expenditure, investing in segments where there are benefits of tax exemption and fiscal incentives.

Related to the demand for cultural and creative goods and services, there are many problems concerning the formation of audience, plus insufficient financial and infrastructural resources. The low educational level combined with lack of leisure time and great distance of the main cultural centers from the low income residential areas leads to the usual audience to be composed of elite classes, especially in great urban centers.

In spite of the mildly disheartening context, there are segments of the Brazilian creative economy emerging or consolidating in this scenario, due to the mentioned creative and cultural diversity, initiatives of entrepreneurs, producers, artists and some institutional actions directed to stimulate the cultural and creative industries (CCIs).

In the last 15 years, there has been a discontinuous but important increase of the scope of cultural policies in Brazil. Given this context, in this paper we intend to analyze two CCI segments in the perspective of employment and innovation, with emphasis in regional comparison. Among various activities, two have stood out in the last ten years: digital games and the fashion industry.

The Brazilian digital games industry is an emerging sector, composed of small and medium size companies highly dependent on imported software. However, the degree of consumption was substantially enhanced by the expanded access to ${ }^{2}$ This term was created by Baumol [1] to treat the centrality of knowledge and creativity in the economic processes of the paradigm created by the Information and Communication Technologies. 
smartphones and other mobile media ${ }^{3}$. Brazil is the fourth biggest consumer and the eleventh producer in the world (NEWZOO, 2016) [3]. Its capacity of interaction has boosted the implementation of technological centers and start-ups aimed at developing games and apps that cover a wide range of purposes related, for example, the serious games, especially in education, health and entertainment.

In regards to the fashion industry, Brazil has a consolidated textile industry, being the $4^{\text {th }}$ greatest producer in the world. In this sector, there has been a combination of experiences shared between traditional knowledge, handicraft, and the development of textiles suitable to the tropical climate. The introduction of fashion weeks helped to create an identity in the national production and to give it international visibility. And this synergy between the traditional and the contemporary was enabled by the work of designers concerned not just with international trends, but also with the knowledge and traits of the different regions of the country.

Concerning to analyze those segments that are important to Brazil creative economy and were benefited by Communication and Information Technologies in different forms, this paper intends to identify the presence of competences in human resources with territorial identity, access and use of innovative resources for production, distribution and financing, besides local differences, in a regional perspective. For such, it is divided in four parts, including this introduction. The second focuses in a theoretical approach on the traits of the Brazilian CCIs. They are marked by various forms of inequality, but yet experience a high level of cultural diversity. In the third part, we analyze the sectorial development in respect to the creation of employment, income, emphasizing the actions and policies directed to both segments. Finally, the article aims to point out what is specific about both sectors, considering how they are incorporated into the world market. We also discuss the possible interaction of these sectors with each other and with other sectors of the creative economy, as well as the producer-consumer interaction as a way of fostering development and innovation networks.

\section{The ICCs in International and Brazilian Literature}

The technological rupture caused the advent of digitalization is imposed since the 1980s. And, as any technological rupture, the Communication and Information Technologies (CITs) affected the way of thinking and living in society, defining new paths for economics, politics and culture. Thus, we observe an increase in the production and consumption of intangible goods, market globalization, growth of the third sector, especially communications, finance, logistics, culture, entertainment, among others. This also increases the need of differentia-

${ }^{3}$ According to IBGE [4]: "In 2014, there was an expansion of the use of internet in all the major regions, but this expansion occurred through equipment other than personal computers ... The internet access using cellphone surpassed the personal computer use in Brazilian households, especially the Northern region, which presented the highest proportion $(92.5 \%)$.” 
tion of products through increase of creativity and knowledge.

The creative economy emerges, in this context, as a production and organization mode, becoming the interest focus of economic, cultural and political actors. It can be understood as a set of policies and actions directed to make established sectors more dynamic, such as music, audio-visual arts, plastic arts, antiquities, performing arts, craftwork, publicity, games and apps, architecture, editing and publication of books, design, fashion, TV and radio, cinema, gastronomy, cultural heritage (both tangible and intangible), et cetera. These sectors have been considered part of the CCIs by the Department of Culture, Media and Sports of the United Kingdom [5], the UNCTAD [6] and many researchers [7] [8] [9] [10].

Even if the tally of activities that are part of the CCIs is variable and depending on the idiosyncrasies of different countries, a consensus has been forming in the economic literature concerning the impact of the CITs on these segments, i.e., the theoretical analysis by means of the use of approaches referring to the evolutionary theory.

According to the evolutionary theory, based on Schumpeter [11], innovation is defined in economic terms as the creation of new products and processes related to the development, distribution and diffusion of the economy, constituting in a force of support of the capitalist dynamic in the long run [10]. The focus of this literature is in science and technology, related to the technical progress, patents, industrial sectors and the tangible production. However, innovation in services, especially the ones related to the CCIs, becomes evident by its aesthetical, symbolical and intellectual aspect. The focus then becomes the creative and organizational nature of innovation [12] [13] suggests that innovation in these limits presents itself, from one hand, as a cultural process and an innovation of product and, from the other, as technological products of the innovation process.

In this way, the CCIs act as a confederation of activities organized around creation, transformation and consumption of knowledge, ideas and cultural symbols. The productive structure creates and diffuses and also becomes a user of the CITs and, thus, it creates a virtuous cycle that modifies and is modified by the evolving technological paradigm.

Potts [14] sees the creative activity as any one that presents this transformation: the union of human creativity and intellectual property, and treats it as a primary resource not only for culture, but also for the economy as a whole. In Potts [15], he points that CCIs are not only intensive in innovation and rapid growth, since they also overflow these advancements to other economic sectors. In other words, they promote spillover effects. Bakshi, McVittie and Simmie [16] also emphasize the role and the strong presence of the creative industries in the innovation systems. In a study on the CCIs in the United Kingdom, they ratify the effects of overflowing and the presence of knowledge spillover effects coming from the CCIs to other sectors of the economy. 
We also have Wijnberg [17], Pratt and Jeffcutt [18] and Lazzeretti [2] that reinforce the use of the evolutionary approach in order to comprehend the relation between the technological innovation and the productive processes in the creative industries. In a synthetic way, the said authors understand that technological innovations under the CITs paradigm promoted modifications in the market structure, companies and, mainly, in the productive processes of the established business in the market, through decentralization of activities and use of 'polyvalent teams', as agents responsible by different phases of production and spreading of symbolic and intangible goods.

In addition to the evolutionary character of the CCIs, another important question is the formation of clusters. Lazzeretti, Boix and Capone [19] emphasize that, even if the market digitalization favours the spatial decentralization of producers and consumers, given that much of what is produced is intangible or virtual, the environment that aggregates creativity ends up increasing business competitiveness, imposing and intensifying the creative process through innovation, creating for both the businesses and the creative entrepreneur the visibility to the success of their product.

Without losing sight of the international literature on the nature and dynamics of the CCIs, in the 1970s, Furtado [20] wrote that the freedom to create is part of the concept of development itself and it is an input for the social transformation, constituting in a way to face social inequalities. This view converges to the proposed role of the CCIs as one of the possible strategies of development, once we comprehend that if creativity and cultural resources exist universally, in abundance (once tangible) and in a "self-generated" way, crossing the frontiers of poverty and underdevelopment. According to Pagliotto [21], such countries would count with conditions similar to the developed economics in terms of talents, entrepreneur instincts, cultural expressions, openness to the new and to the different. However, this potential is little explored in terms of wealth creation. The interaction of economic, cultural and social aspects between themselves and the technology (especially network connections) the intellectual property and tourism would thus allow the creation of strategies that would demand relatively small investments and weak entry barriers, that could go "from zero" to possible connections with the global economy.

On the other hand, as Paglioto [21] points out that the entrance of peripheral countries can contribute to maintain the external dependence, once that the initial conditions continue being unequal in many structural aspects, which reinforces the existence of a dual productive system in terms that are technological, educational, of worker insertion (which represents high rates of informality).

The unequal conditions must be considered in strategies for the propagation of the creative economy in peripheral countries. In 2008, the then Brazilian Minister of Culture, Gilberto Gil, wrote that "the diverse and sophisticated Brazilian cultural production, in addition to its symbolic and social relevance, should be understood as one of the greatest economic assets of the country, capable of 
creating development" (apud LEITÃO, 2016 ${ }^{4}$ ) [22]. Since then, with the support of the Ministry of Culture, a series of policies and actions in the three spheres were implemented, but little consolidated due to the political discontinuity.

Table A1 (in the appendix) shows some of the main actions in the Brazilian creative economy, both public and private, in the last 15 years, emphasizing specific initiatives related to the promotion of fashion and games' sectors, and their acknowledgment as cultural goods.

Between 2003 and 2010, the Ministry of Culture (MinC) flourished, expanding its activities, including towards the creative economy ${ }^{5}$. The creation of an International Centre of Creative Economy (ICCE) has been proposed to be established in Salvador, Bahia, however it was not taken forward, as well as the Creative Economy Secretary Plan (2011) and Creative Brazil Plan (2012). Due to the fact that policies to foment the creative economy were not taken forward, many of the efforts converted into a simple rhetorical exercise.

However, some actions did create results: databases on the creative sectors have been created $^{6}$, the establishment of the Procult credit line from the $\mathrm{BNDES}^{7}$, that financed many projects of the creative economy, and the support of micro and small creative entrepreneurs by SEBRAE ${ }^{8}$. The National Culture Plan, from 2010, can also be considered a fundamental point, because it consolidated an ample comprehension of culture capable of encompassing the many sectors of the creative economy. The short existence of the Creative Economy Secretariat was a sign of the crisis in the ministry and the current government ${ }^{9}$.

Considered what has been exposed, the next section develops a sectorial approach to analyze how the instable expansion of the creative economy in Brazil reflects in practical terms in two of its most important segments in the country: fashion and digital games. They will help us to understand different potentials to the development, in the matter of innovation and employment.

\section{Analysis of the Games and Fashion Sectors in the Institutional and Creation of Employment Perspective}

As Table A1 shows, policies and actions implemented for CCIs in Brazil were not made in a systematic and articulated form. If the Creative Brazil Plan was fully implemented, it could be the main force driving the creative economy, but it was aborted. Thus, initiatives of private association and individual entrepreneurs became the main way to strengthen the creative segments. It was not different for the games and fashion segments.

\footnotetext{
${ }^{4}$ In an article published in Folha de São Paulo, 02/03/2008, co-authored with the coordinator of the Program of Development of the Economy of Culture (Prodec), Paula Porta. Available at: http://www.cultura.gov.br/site/2008/02/03/economiadacultura2/.

${ }^{5}$ The panel on Creative Economy in the XI UNCTAD conference, in São Paulo, in 2004, can be considered the first discussion about this issue in Brazil (MIGUEZ, 2011) [23].

${ }^{6}$ The first mapping of the Brazilian creative industry was published by FIRJAN (Federation of the Industries of Rio de Janeiro), in 2008 [24].

${ }^{7}$ National Bank of Economic and Social Development.

${ }^{8}$ Brazilian Service to Support Micro and Small Businesses.

${ }^{9}$ In 2017, three different ministers took office.
} 
Figure 1 shows the geographical distribution of both industries. Given the distance between centers, there are problems in institutional articulation. They must be dealt with so that national and international projection can be attained, without losing touch with the local traits. Due to the continental dimensions of the country, we can observe that cities where the clusters are located are dispersed through the territory, and that they are marked by high income inequality and, at the same time, cultural diversity. The Northeast region, location of the metropolitan regions of Fortaleza (RMF) and Recife (RMR), has less availability of resources. On the other hand, the metropolitan regions of São Paulo (RMSP) and Rio de Janeiro (RMRJ) have better access to credit, consumer market and qualified workers. Porto Alegre (RMPA) and Belo Horizonte (RMBH) are in a middle term between both.

\subsection{Digital Games}

The digital games industry can represent a key sector to the development of the creative culture as a whole, once that its production has an interface with other

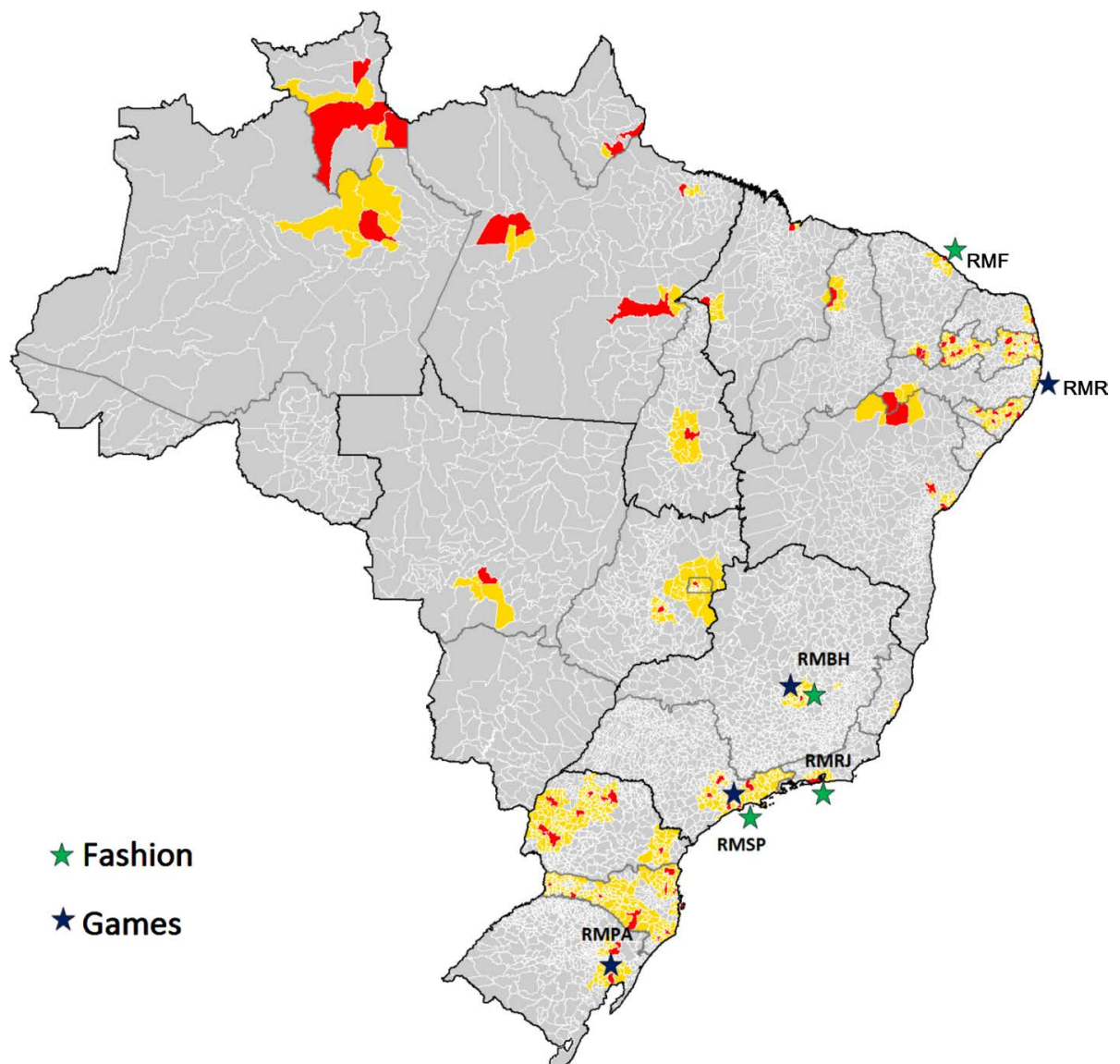

Source: Map extracted from Wikipedia (author: Volanick2) and modified by the authors according to license permissions CC BY-SA 4.0

(https://commons.wikimedia.org/wiki/File:Regioesmetropolitanas2015.png).

Figure 1. Brazilian Metropolitan Regions, 2015, highlighting the regions the games (blue) and in the fashion (green) sectors. 
productive sectors as a whole that involve the audio-visual, design and development of CITs. Former minister Gilberto Gil's speech at the 2004 Electronic Game Show can be considered "the first public manifestation of government support to the sector of digital games" [25], when the digital games market was at an incipient phase. In the same year, the public notice Jogos BR is published and it proposed to finance projects on national games production. The public notice was made in a partnership with the newly created Abragames, a developers' association created to provide support to developers. Besides Abragames, there are other two important associations: the Association of Promotion of Excellence in Brazilian Software (Softex), founded in 1996 to promote quality and competitiveness in Brazilian software industry, and the Commercial and Cultural Association of Games (Acigames), founded in 2010, which aims to regulate the electronic games commerce.

The Procult credit line also covers digital games. More than that, it has launched three calls for proposals from Criatec, an investment fund focused on early-stage companies that need capital and management support in order to ensure strong value and accelerate its growth. In 2011, the digital games sector becomes eligible to receive resources from the Rouanet law of fiscal incentive to the culture. Besides the MinC, the Ministry of Communications also starts supporting the sector in 2013, by conditioning tax exemptions to a minimal national content in apps developed in the country and, in 2014, it launches the InovaApps public notice to support the creation of public interest apps for mobile devices and digital TV. In December 2016, Ancine (National Cinema Agency), through a supportive program called Brasil de Todas as Telas (Brazil of All Screens), launched the first specific initiative for the digital games sector, with a $\mathrm{R} \$ 10$ million budget from the Audio-visual Sector Fund (FSA) to finance the development of 24 projects of Brazilian games [26]. The initiative was well received by the members of Abragames [27]. In spite of these punctual initiatives, it is not possible to identify a clear public policy to the sector, encompassing regulation and an industrial policy that promotes international competitiveness.

Although not directly identified as policies for the creative economy, there is a number of state and municipal programs that aim to encourage information technology (IT) entrepreneurship, especially apps and games development. In some cases, technology parks are created within educational institutions in partnerships with other entities. In São Paulo, which has the most developed technology network, there are start-ups with platforms to promote work and interchange among entrepreneurs. They organize major events and promote interaction between them and the most diverse segments of the Brazilian economy. In Porto Alegre, there is the ADJogos-RS (Association of Digital Game Developers), with 30 members, the biggest regional association in Brazil [28]. In Recife, Porto Digital, established in 2001, was specialized initially in sectors related to CITs, expanding, in 2010, to Portomídia (related to games, multimedia, animation, design, photography and music), taking the term creative economy in its 
complete scope. In Belo Horizonte, these initiatives are more recent ${ }^{10}$ and less integrated with other policies.

The companies of the sector in São Paulo, Recife, Belo Horizonte and Porto Alegre are seeking to have a closer interaction between each other. Innovative clusters are being created, taking advantage of the digital hubs that these cities have [30]. A number of actions have been taken by these communities to brand the ecosystem and project it in the national scenario. Considering Silicon Park in São Paulo; Porto Digital in Recife Antigo; San Pedro Valley in Belo Horizonte and the pole in Porto Alegre, yet to be named, it is possible to identify 50 start-ups in the games and apps sector. Near these cities, there are other poles, like the Tecnosinos, in São Leopoldo. In these environments, as well as in government programs that are not connected to universities, the companies are incubated, accelerated, mentored, and inserted into a network formed by other ventures of the segment, having the opportunity to participate in national and international events.

As Zambon [25] emphasizes, in the digital games market, the innovation is inherent and historically follows the development of this industry starting from the evolution of computational capacity, which strengthens the competitiveness. This is reflected in the data: while the services sector registered a fall of $4.6 \%$ in 2016 , the IT sector showed an increase of $4.2 \%$. Analysts consider that the digital games market was responsible for this increase [31].

About $75 \%$ of Brazilian producers had, in 2013, annual revenue up to $\$ 80,000$ USD [32]. The majority of the Brazilian developers run small businesses, with an average of 8.5 employees per company, including partners, according to a BNDES study conducted with 133 companies [32]. Only five employ more than 30 workers. Furthermore, Fleury et al. [32] show that most Brazilian companies use resources from their families or from other individuals as forms of financing (64.7\%), followed by incubators (26.3\%), and from the non-reimbursable resources $(18.8 \%)$. Also, as stated by the same study, a large number of companies work with games aimed at entertainment (97.8\%), serious games (48.1\%) and advergames $^{11}(30.1 \%)$.

The gaming sector is included as part of non-customizable computer programs in the National Classification of Economic Activities (CNAE) ${ }^{12}$. Considering the data from the RAIS for this specific rubric, the number of establishments of this sector diminished between 2006 (consolidation year of the sector in the country) and 2015 (last available database), as it can be seen in Table 1. The reduction in the number of establishments from 11,778 to 8095 coincides with an increase in the number of formal ties, which jumped from 17,538 in 2006 to 46,056 in 2015. This performance suggests that there is a concentration

\footnotetext{
${ }^{10}$ The Mineira Association of Games (GAMinG) was created in 2016. It has 26 associated development studios, as well as 11 support companies and 7 educational institutions, according to Raoni Aldrich Dorim, president of the association and partner of Mopix Games [29].

${ }^{11}$ Games developed to be interactive advertisements for other companies.

${ }^{12}$ Version 2.0, 2006.
} 
Table 1. CNAE subclass development and licensing of non-customizable computer programs-including games' production-characterizing the formal employment between 2006 and 2015.

\begin{tabular}{cccc}
\hline & $\mathbf{2 0 0 6}$ & $\mathbf{2 0 1 0}$ & $\mathbf{2 0 1 5}$ \\
\hline Total of establishments & 11,778 & 9358 & 8095 \\
Establishments up to 9 employees & 97.39 & 94.18 & 91.02 \\
Total of employees ${ }^{1}$ & 17,538 & 32,182 & 46,056 \\
Average wage $(\mathrm{R} \$)^{2}$ & 2335.99 & 2540.65 & 4252.10 \\
Average age & 30 & 31 & 32 \\
Women participation (\%) & 34.70 & 34.11 & 33.27 \\
Higher education $(\%)^{3}$ & 44.94 & 50.72 & 58.37 \\
\hline
\end{tabular}

Source: RAIS, 2006, 2010 e 2015. Considering only active ties in December of the same year. ${ }^{1}$ Parameter: Total of formal jobs in Brazil: 2006-35,155 (thousand); 2010-44,068 (thousand); 2015-48,061 (thousand). (RAIS-presentation). ${ }^{2}$ Nominal values. As a parameter, we have that the minimum wage in 2006 was $\mathrm{R} \$ 350.00$, in 2010 it was $\mathrm{R} \$ 510.00$ and in $2015 \mathrm{R} \$ 788.00$ (DIEESE, 2017). ${ }^{3}$ Percentage of workers with schooling equal to or higher than complete tertiary education.

of companies in the sector. This result is confirmed by the number of businesses with up to nine employees, which decreased from $97.39 \%$ in 2006 to $91.02 \%$ in 2015. The small business profile, however, is in consonance with what was indicated by (FLEURY et al., 2014a) [32], identifying an average of 8.5 employees per company.

In nominal terms, the average income almost doubled in the period. Yet, in US dollars, it remained stable. In 2006, the industry workers received, on average, $\mathrm{R} \$ 2355.99$ or $1086 \mathrm{USD}^{13}$. In 2015 , the average monthly remuneration was $\mathrm{R} \$ 4252.10$ or $1099 \mathrm{USD}^{14}$. Regarding the employee profile in this segment, they are in average 30 years old, mostly men (about 70\%), and mainly highly educated. The participation of workers with this profile has increased in the period previously mentioned. In Brazil, the workforce with the same level of education is less than $20 \%$, while in the games and apps segment it has already reached $58.37 \%$ in 2015 . This difference is caused by the fact this segment demands specialization in universities, besides fluency in English, something still not broadly available in the Brazilian workforce.

The qualification of middle class young adults is sometimes explored by the international market through outsourcing to Brazil services related to games development. The problem of outsourcing is that it does not create intellectual property returns. On the other hand, the high tax costs hinder the Brazilian competitiveness when comparing to China and India. In the metropolitan areas, there are a good number of young adults with high educational level and fluency in English. This workforce is capable of developing every kind of activity, such as games development, for a lower cost than in developed countries. Brazil has the greatest number of Java programmers in the entire world and it is the second in

\footnotetext{
${ }^{13}$ The Real/US Dollar Exchange rate was 2.15 in December 2006.

${ }^{14}$ The Real/US Dollar Exchange rate was 3.87 in December 2015.
} 
mainframe programmers (COBOL).

\subsection{Fashion Industry}

Fashion can be considered another key sector for the development of the creative economy in Brazil, especially because of its consolidated relation with the industrial sector. The institutional policy for the Brazilian fashion industry involves various sectors, seeking international projection. With the liberalization of imports in the 1990s, the Brazilian textile industry was negatively affected. It was outdated and unprepared to face competition from imported products, which had better quality and lower prices. It was hence subject of a quick modernization [33]. From this decade on, Brazil was influenced by international fashion trends ${ }^{15}$ and this forced national stylists to return to their regional identities.

As a consequence, fashion designers focusing on reflecting the local, popular culture and a Brazilian identity have been promoted since then. Lino Villaventura (Fortaleza), Ronaldo Fraga (Belo Horizonte) and Isabela Capeto (São Paulo) are examples of this trend. Each one uses regional characteristics to show the cultural diversity of the country, creating a productive capacity that improves the visibility of groups of production previously limited to handicrafts. Such movement has raised self-esteem, empowerment and autonomy among the actors involved in this process. For this reason, fashion courses were established in several Brazilian state capitals by the end of the 1990s. Those courses provided a more comprehensive repertoire for the students, expanding the participation of fashion in the productive chain and also integrating women in the academic formation ${ }^{16}$.

As part of these institutional policies, trade schools such as SEBRAE and SENAI MODA TEC provide a primary formation in fashion. SEBRAE provides professional training for entrepreneurs, in order to evaluate and organize the viability of their businesses, not restricted to fashion. This has been important for designers since their undergraduate courses only improve their creative and technical skills. In terms of enabling a business, there is little preparation, making it difficult to start a professional life. In this sense, SEBRAE's programs have been important in the complementary training for the technical stylists. SENAI Moda Tec has maintained an important place in design, which relies on a vast technical knowledge that cannot be totally absorbed by the critical thought of academic education.

In addition, the textile industry, which had reorganized itself since the 1980s. The institutional policies sponsored by the Brazilian Association of Textile and Fashion Industry (ABIT) have acted to expand national and international markets. They bring into contact brands whose creative products have good quality

\footnotetext{
${ }^{15}$ For example, in 1990, the international luxury brands store Daslu was inaugurated in São Paulo, turning into a centre to spread international fashion trends throughout the country.

${ }^{16}$ In 2007, according to SCALZO [33], there was approximately 80 undergraduate fashion schools and 40 specialization courses.
} 
but that have problems to reach international markets. Those policies set up anchors capable of promoting and establishing important networks. In fact, these actions were developed in order to enlarge the connection between the public and the fashion industry ${ }^{17}$.

Last but not least, combined with the Brazilian fashion expansion, a new concept of fashion modelling emerged in Brazil after the übermodel Gisele Bündchen. Along with her image that won the world, Brazil was able to transform the formal fashion events into real spectacles. The best example is the São Paulo Fashion Week (SPFW), created in 2001, being the most important. It marked the professionalization and growth of the sector. Roughly the same time, a unified Brazilian fashion calendar was established, with increasingly bigger events/parades of this sector throughout the country. In the underground scene, the Casa dos Criadores (1997) was created to be an event to discover young designers and new markets, using alternative spaces.

In this perspective, due to their creativity and production capacity, these events have inspiration from other important Brazilian cultural events such as carnival parades, the Parintins oxen and religious festivals. Fashion is now a part of Brazilian Cultural Patrimony.

The acknowledgement of the cultural value of fashion can be identified in the words of the former minister Gilberto Gil during the 2007 Marketing for Fashion Seminary, placing the fashion as "vital part of the Brazilian culture." In 2008, the System Moda Brasil was created, linked to the Ministry of Development, Industry and Foreign Trade, gathering different government representatives and the main private association of the sector, with objective of developing the fashion chain and promotion of Brazilian fashion abroad. In 2010, the MinC publishes the first sectorial research about fashion in its cultural perspective, seeking to contribute for the insertion of fashion in the national agenda of cultural public policies. Also, in this year, the I National Fashion Seminar takes place, during which the Fashion Sector Collegiate of the National Council of Cultural Policies is elected.

By fashion industry we understand that it is the core of design, creation and innovation that gives support to the textile and confection industry, plus shoes and accessories. The FIRJAN considers as part of this creative core the occupations of fashion designers, tailors, models, jewellers and artisans related to production of clothes, shoes and accessories. This core, in 2015, represents 49,000 workers, with an average remuneration of $\mathrm{R} \$ 1.724 .36 \%$ of them are in the state of São Paulo, which has more than half the fashion-related courses [34].

However, the impacts of the fashion industry, in terms of creation of employment and income, cannot restrict themselves to its creative core, due to its importance to the chain as a whole.

In a general way, the fashion as a concept influences many steps of the tex-

${ }^{17}$ For example, Auá, a brand from Minas Gerais, was created from a combination of art and modeling, away from the semiannual parades trends. Auá was invited by the ABIT to take part in the Paris fair "Who is next?" in 2011, 2012 and 2013 in order to promote Brazilian artistic fashion works. 
tile productive chain, starting from the weaving to the final product. The chemical industry, for example, can be directed to better production of inputs, weaving textures or colors. The research on development and innovation also includes the creative design and modeling. The characterization of the pieces of clothing and textiles can also be a factor of strengthening of the external market, given that the specifiers of the exported pieces and accessories diminish the susceptibility of the exports to the price, to external competition and exchange rates; contrary to the common clothes and textiles, proper of the production focused on quantity and low cost. Likewise, the internal demand is strengthened as well, when there is an identification of the consumer with the design aggregated to the clothes [34].

Thus, to define the elements part of the fashion chain, using data from RAIS, we used the study of the João Pinheiro Foundation for the state of Minas Gerais in 2016 and the study of FIRJAN for the state of Rio de Janeiro, made in the same year.

In terms of employment creation, we have three segments selected from the RAIS data, in the same years: wiring and weaving; clothing industry; and production of footwear, accessories, jewellery and bijouteries (Table 2). Among them, the clothing industry hold the largest number of businesses. This happens because Brazil is the fifth textile producer in the world, as pointed by the Brazilian Association of Textile Industry and Fashion (ABIT) ${ }^{18}$. The increase of clothing factories, footwear, accessories, jewellery and bijouteries between 2006 and 2010 is probably explained by the expansionary cycle in the Brazilian economy. On the other hand, it stagnates with the slowdown of the economic activity level between 2010 and 2015. The same phenomenon was verified in labor market. Data published by ABIT indicate a recovery from this scenario in 2017, after a two-year recession [35].

Regarding small companies, there is no change between the two extreme years of the series, except for an increase of almost three points in the subsectors of wiring and weaving. The average wage is much lower than in the digital games and apps sector, with a great emphasis on the subsectors of clothing, footwear, accessories, jewellery, and bijouteries. In the fashion production chain, the average monthly income was $\mathrm{R} \$ 1371.33$ or 354 USD in 2015 , three times smaller than in the games and apps sector.

The workers' average age is somewhat higher, especially in wiring and weaving, and women predominate in clothing industry and also in footwear and accessories, although in a smaller proportion. The increase in the participation of workers with secondary level education in all subsectors between 2006 and 2015 is highlighted in Table 2, which is lower than the qualification of the employees in the games and apps sector. Otherwise, because it is a traditional and much more complex sector, the fashion industry has a broader potential for creating jobs for workers with different levels of education, thus it is not comparable to

${ }^{18}$ http://www.abit.org.br/cont/perfil-do-setor. 
Table 2. Fashion productive chain in Brazil-evolution of formal employment, average wage, average age, and women participation between 2006 and 2015 by subsectors.

\begin{tabular}{|c|c|c|c|c|}
\hline Year & $\begin{array}{l}\text { Wiring and } \\
\text { Weaving }{ }^{1}\end{array}$ & Clothing ${ }^{2}$ & $\begin{array}{l}\text { Footwear, } \\
\text { Accessories Jewellry, } \\
\text { and Bijou }\end{array}$ & Total $^{4}$ \\
\hline \multicolumn{5}{|c|}{ Total of establishments } \\
\hline 2006 & 10,188 & 95,491 & 23,709 & 129,388 \\
\hline 2010 & 10,427 & 102,851 & 25,208 & 138,486 \\
\hline 2015 & 10,141 & 96,526 & 22,527 & 129,194 \\
\hline \multicolumn{5}{|c|}{ Establishments with up to 9 employees (\%) } \\
\hline 2006 & 77.56 & 87.04 & 82.61 & 85.48 \\
\hline 2010 & 77.16 & 85.60 & 80.77 & 84.08 \\
\hline 2015 & 80.04 & 86.68 & 82.61 & 85.45 \\
\hline \multicolumn{5}{|c|}{ Total of employees } \\
\hline 2006 & 224,035 & 551,014 & 336,087 & $1,111,136$ \\
\hline 2010 & 234,187 & 681,394 & 384,806 & $1,300,387$ \\
\hline 2015 & 192,461 & 590,629 & 315,181 & $1,098,271$ \\
\hline \multicolumn{5}{|c|}{ Average age ( $\mathrm{R} \$$ ) } \\
\hline 2006 & 897.30 & 564.38 & 590.63 & 639.44 \\
\hline 2010 & 1199.77 & 790.35 & 793.30 & 864.95 \\
\hline 2015 & 1791.76 & 1288.122 & 1270.511 & 1371.325 \\
\hline \multicolumn{5}{|c|}{ Average age } \\
\hline 2006 & 34 & 32 & 30 & 32 \\
\hline 2010 & 34 & 33 & 31 & 33 \\
\hline 2015 & 36 & 35 & 33 & 35 \\
\hline \multicolumn{5}{|c|}{ Women participation (\%) } \\
\hline 2006 & 29.29 & 74.50 & 50.58 & 58.15 \\
\hline 2010 & 30.91 & 74.45 & 52.52 & 60.12 \\
\hline 2015 & 31.92 & 74.17 & 52.98 & 60.68 \\
\hline \multicolumn{5}{|c|}{ Higher education $(\%)^{5}$} \\
\hline 2006 & 33.63 & 34.13 & 28.73 & 32.4 \\
\hline 2010 & 43.82 & 47.09 & 38.32 & 43.91 \\
\hline 2015 & 50.51 & 58.82 & 47.50 & 54.11 \\
\hline
\end{tabular}

Source: RAIS, 2006, 2010 e 2015. Considering only employments with active ties in December of the same year. ${ }^{1}$ It comprises textile products manufactures (CNAE 2.0: 13111, 13120, 13138, 13146, 13219, 13227, $13235,13308,13405$ ); tanning and other leather preparations (CNAE 2.0-15106); and artificial and synthetic fibres manufacture (CNAE 2.0-20401) [36]. ${ }^{2}$ It comprises clothing articles and accessories manufacture (CNAE 2.0: 14118, 14126, 14142, 4215, 14223) (FJP, 2016, p. 22). ${ }^{3}$ It comprises travel goods, bags and similar manufactures (CNAE 2.0-15211); the footwear manufacture (CNAE 2.0: 15319, 15327, 15335, 15394, 15408); and jewelry and similar manufactures (CNAE 2.0: 32116, 32124) (FJP, 2016, p. 22) [33]. It comprises the three links present in the other columns: wiring and weaving; clothing industry; and footwear, jewellry and bijouterie production. ${ }^{5}$ Percentage of workers with schooling equal to or higher than complete secondary education.

the recent industry of development of digital games. 
Summarizing, the analysis of the two segments in the CCIs' profile shows different configurations of companies' size, average income, educational level and gender composition. However, those differences disregard spillover potential and cross-fertilization between the fashion and games and apps sectors, as we are going to present in our conclusion.

\section{Final Considerations}

Digitalization has allowed the exchange of a variety of information between users. The creative industry is one of the sectors that have benefited most from it. In first place, it allows the allocation of less work or even extinction of certain functions, favoring spatial and temporal flexibility. The content production demands allocation of time and financial resources, but the dissemination of such content costs almost nothing. This increases the capillarity and brings together customer and developers, often anonymously, transcending the concept of a local market into a global one, which has contributed to reduce the number of links in the gaming and apps value chains. For example, app stores have become substitutes for computer distributors.

This trend is already being observed in the sectors connected to the fashion chain [37]. Some authors claim that the sector is going through a "fourth industrial revolution", reforming its entire value chain through scientific and technological bases that are different from those currently employed. With this new scenario in mind, ABIT itself organized an innovation mission in Silicon Valley in 2015, looking to share technology from different segments that could inspire the wiring and weaving sectors [38].

In this perspective, the possibilities of interaction between the different sectors of creative economy become evident. The fashion and digital games sectors are an example of overflowing and cross-fertilization effects. Another clear example is the expansion of the communication channels between consumers and producers in the fashion industry through the "fast fashion" ${ }^{19}$. Considering the increasingly easier and more dynamic access to internet, fast fashion approximates consumers to the production chain, by starting the mass customization process in the factories, and giving designers and promoters a new role. This interaction in the marketing channels can be potentially enlarged using apps that apply virtualization technologies to clothing measurement (using 3D mirrors) and advergames.

The digital gaming sector has a development line based on "hyperreality", which relies on precise movements of 3D characters created with help of specialized software ${ }^{20}$. With a market open to development of national technologies ${ }^{21}$ and potential to cooperate with other sectors, such as the fashion one, this sector "continues to seek more realistic and mechanically accurate models" [37]. Co-

\footnotetext{
19"Fast fashion can also be understood as a strategy to offer high-quality, fashion-intensive, high-frequency collections that seek to meet consumer demand at its peak, but at relatively low prices" [37].

${ }^{20}$ For example, the British company Natural Motion. http://www.naturalmotion.com/.

${ }^{21}$ For example, the Brazilian company Audaces. http://www.audaces.com/.
} 
operation with other technology-intensive chains can be further extended to smart clothes and wearable technologies development.

Another important form of interaction between the two sectors, regarding the expected changes in the fashion sector and the current developments in the games and apps sector, would be the use of "serious games" to train new professional profiles appropriate to the changes in the productive base:

The use of inputs from other chains, such as sensors and electronic actuators, and photonic filaments, for example, creates unprecedented complexities for the clothing technology, from its conception to its actual manufacture. Former seamstresses should be able to operate different machines in assembly processes involving other skills, other than those that have been required for manual workers for centuries [39].

These lowly qualified professionals mentioned above would have the opportunity to increase their skills to deal with computational tools, digital automation systems, intensive use of data, and new business models. As Fleury et al. [40] point out, the games bring realism and motivation, with potential for significant reduction in training time and greater employee engagement.

On the other hand, the digital gaming industry can also benefit from experiences of the fashion industry throughout its long history in the country, and for being the last full Western textile chain (from fibre production to catwalks). As we observed, the opening to international markets has promoted a national production strongly focused on the values and creativity of the Brazilian identity, which it is still hard to notice in the digital gaming sector. We are still too dependent on foreign content and design. However, an exception would be the game titled "Dream of Jequi", whose theme and art are inspired by the Jequitinhonha Valley in Minas Gerais. The game was selected to represent Brazil in the "Imagine Cup", a competition of technological projects, innovation and games, promoted by Microsoft.

\section{Conclusions}

This paper intends to analyze Brazilian CCIs. They are marked by various forms of inequality, but yet experience a high level of cultural diversity. For this reason, we describe the sectorial development in respect to the creation of employment, income, emphasizing the actions and policies directed to two segments, games and fashion, through information provided by secondary data.

The analysis of these two sectors of the CCIs in a peripheral country sought to put in evidence the institutional differences in the foment of their foundations, as well as the creation of value. In this case, the investigation through secondary data (RAIS) shows how employment and income position themselves. Certainly, a case study, recurring to primary data, would turn more evident the formation of clusters in the mentioned metropolitan regions, their innovative processes and its interaction with other segments. Anyway, this paper presented two relevant CCI sectors for the Brazilian industry and their insertion in the world sce- 
nario, besides their local traits in the distribution throughout the territory, the capacity of using CITs and the formation of a cultural identity, important attributes in the constitution of a creative economy.

\section{References}

[1] Baumol, W.J. (2006) The Arts in the "New Economy". In: Throsby, D. and Ginsburg, V., Eds., Handbook of the Economics of Art and Culture, Elsevier, Amsterdam, Vol. 1, 339-358.

[2] Lazzeretti, L. (2013) Cultural and Creative Industries: An Introduction. In: Lazzeretti, L., Ed., Creative Industries and Innovation in Europe Concepts, Measures and Comparative Case Studies, Routledge, London, 65-85.

[3] NEWZOO (2016) Global Games Market Report Premium.

[4] IBGE (2016) Instituto Brasileiro de Geografia e Estatística. Acesso à Internet e à Televisão e Posse de Telefone Móvel Celular para Uso Pessoal. IBGE, Rio de Janeiro.

[5] DCMS (1998) Creative Industries Mapping Document. London.

[6] UNCTAD (2010) Creative Economy Report. UNCTAD/UNDP.

[7] Howkins, J. (2001) The Creative Economy: How People Make Money from Ideas, Penguin.

[8] Hartley, J. (2005) Creative Industries. Blackwell Pub.

[9] Cunningham, S. (2002) From Cultural to Creative Industries: Theory, Industry and Policy Implications. Media International Australia Incorporating Culture and Policy, SAGE Publications, Thousand Oaks, Vol. 102, 54-65.

[10] Nelson, R.R. and Winter, S.G. (2009) An Evolutionary Theory of Economic Change. Harvard University Press, Cambridge.

[11] Schumpeter, J. (1942) The Theory of Economic Development. Harvard University Press, Cambridge.

[12] Petrova, L. (2016) Spillovers and the Processo of Cultural Valorization. http://www.acei2016.uva.es/event_detail/3433/accepted_abstracts/19thinternational -conference-on-cultural-economics.html

[13] Jaaniste, L. (2009) Placing the Creative Sector within Innovation: The Full Gamut. Innovation: Management, Policy \& Practice, 11, 215-229. https://doi.org/10.5172/impp.11.2.215

[14] Potts, J. (2007) Evolutionary Institutional Economics. Journal of Economic Issues, 41, 341-350. https://doi.org/10.1080/00213624.2007.11507020

[15] Potts, J. (2011) Creative Industries and Economic Evolution. Edward Elgar, Cheltenham. https://doi.org/10.4337/9780857930705

[16] Bakhshi, H., Mcvitte, E. and Simmie, J. (2008) Creating Innovation: Do Creative Industries Support Innovation in the Wider Economy? NESTA, London.

[17] Wijnberg, N.M. (1995) Selection Processes and Appropriability in Art, Science and Technology. Journal of Cultural Economics, 19, 221-235. https://doi.org/10.1007/BF01074051

[18] Pratt, A.C. and Jeffcutt, P. (2009) Creativity, Innovation in the Cultural Economy. Routledge, London.

[19] Lazzeretti, L., Boix, R. and Capone, F. (2013) Why Do Creative Industries Cluster. In: Creative Industries and Innovation in Europe Concepts, Measures and Com- 
parative Case Studies, Routledge, London, 23-44.

[20] Furtado, C. (2008) Criatividade e dependência na civilização industrial. Companhia das Letras, São Paulo.

[21] Paglioto, B.F. (2016) Economia Criativa: Mediação entre cultura e desenvolvimento. In: Leitão, C. and Machado, A.F., Eds., Por um Brasil Criativo: Significados, Desafios e Perspectivas da Economia Criativa Brasileira, Editora Código, Belo Horizonte.

[22] Leitão, C. (2016) Ter ou não ter direito à criatividade, eis a questão: Sobre desafios, os impasses e as perspectivas de um Brasil Criativo. In: Leitão, C. and Machado, A.F., Eds., Por um Brasil Criativo: Significados, Desafios e Perspectivas da Economia Criativa Brasileira, Editora Código, Belo Horizonte.

[23] Miguez, P. (2011) A economia da cultura como campo de estudos e a novidade da economia criativa. In: Brasil, Ed., Ministério da Cultura. Plano da Secretaria de Economia Criativa: Políticas, diretrizes e ações. 2011-2014, 2nd Edition, Ministério da Cultura, Brasília.

[24] FIRJAN (2015) Mapeamento da Indústria Criativa no Brasil. http://www.firjan.com.br/economiacriativa/pages/consulta.aspx

[25] Zambon, P.S. (2015) Entrando na partida: A formulação de políticas de comunicação e cultura para jogos digitais no Brasil entre 2003 e 2014. 2015. Dissertação (Mestrado em Comunicação), Faculdade de Arquitetura, Artes e Comunicação, Universidade Estadual Paulista, Bauru.

[26] Brasil (2016) Ministério da Cultura, Agência Nacional de Cinema. Programa Brasil de Todas as Telas vai investir R\$ 10 milhões no desenvolvimento de jogos eletrônicos.

http://www.ancine.gov.br/sala-imprensa/noticias/programa-brasil-de-todas-telas-va i-investir-r-10-milh-es-no-desenvolvimento-0

[27] Abragames (2016) Ancine lança primeiro edital de R\$10 milhões para a Produção Brasileira de Games. Newsletter de Fim de Ano.

http://www.abragames.org/newsletter-de-fim-de-ano-2016/ancine-lanca-1-edital-de -r-10-milhoes-para-a-producao-brasileira-de-games

[28] Núñez, T. (2016) A Indústria de Jogos Digitais no Rio Grande do Sul. Carta de Conjuntura FEE, ano 25, n. 2.

[29] Silveira, D. (2017) Número de desenvolvedores de games cresce $600 \%$ em 8 anos, diz associação. G1, Rio de Janeiro.

http://g1.globo.com/economia/negocios/noticia/numero-de-desenvolvedores-de-ga mes-cresce-600-em-8-anos-diz-associacao.ghtml

[30] Loureiro, P.M., Las Casas, D., Machado, A.F. and Simões, R.F. (2016) Centralidade digital e redes urbanas: um estudo da hierarquia digital dos municípios brasileiros, ANAIS. $44^{\circ}$ Encontro Nacional da ANPEC.

[31] Sales, R. (2017) Volume do setor de serviços sobe 0,1\% em novembro, mas cai 5\% no ano. Valor Econômico, Rio de Janeiro.

http://www.valor.com.br/brasil/4833996/volume-do-setor-de-servicos-sobe-01-emnovembro-mas-cai-5-no-ano

[32] Fleury, A., Sakuda, L.O. and Cordeiro, J.H.D. (2014) I Censo da Indústria Brasileira de Jogos Digitais, com Vocabulário Técnico sobre a IBJD. Pesquisa do GEDI Games, NPGT, Escola Politécnica, USP, para o BNDES.

[33] Scalzo, M. (2009) Trinta anos de moda no Brasil: Uma breve história. Editora Livre, São Paulo.

[34] Brasil (2011) Ministério da Cultura. Economia e Cultura da Moda no Brasil. Dez, 
São Paulo.

[35] Camargo, C. (2017) Abit divulga dados de 2016 e projeção para 2017 para o setor de moda. Moda Works.

http://www.modaworks.com.br/site/abit-divulga-dados-de-2016-e-projecao-para-2 017-para-o-setor-de-moda/2017/02/01/

[36] FJP Fundação João Pinheiro (2016) Cadeia Produtiva da Moda de Minas Gerias: Delimitação e Caracterização. Maio, Belo Horizonte.

[37] Bruno, F.S. (2016) A quarta revolução industrial do setor têxtil e de confecção: A visão de futuro para 2030. Estação das Letras e Cores, São Paulo.

[38] ABIT Associação Brasileira da Indústria Têxtil e da Confecção (2015) Relatório de Atividades ABIT 2015.

[39] ABDI Agência Brasileira de Desenvolvimento Industrial (2010) Estudo Prospectivo Têxtil e Confecção. Série Cadernos da Indústria ABDI, Vol. 18, Brasília.

[40] Fleury, A., Sakuda, L.O. and Cordeiro, J.H.D. (2014) Mapeamento da Indústria Brasileira e Global de Jogos Digitais. Pesquisa do GEDI Games, NPGT, Escola Politécnica, USP, para o BNDES. 


\section{Appendix}

Table A1. Chronology of policies and actions related to the foment of the Creative Economy in Brazil, with emphasis on digital games and fashion sectors.

\begin{tabular}{|c|c|c|c|}
\hline $\begin{array}{l}\text { Period/Minister } \\
\text { of Culture }\end{array}$ & Year & Range & Policy/Action \\
\hline \multirow{6}{*}{$\begin{array}{l}\text { 2003-2008 } \\
\text { Gilberto Gil }\end{array}$} & \multirow{4}{*}{2004} & National & XI UNCTAD Conference in São Paulo \\
\hline & & National & Proposal for the creation of the CIEC \\
\hline & & National & $1^{\text {st }}$ edition of the Jogos BR public notice \\
\hline & & National & Foundation of ABRAGAMES \\
\hline & 2006 & National & Release of the BNDES Procult \\
\hline & 2007 & National & $\begin{array}{l}\text { Gilberto Gil's speech on the International Seminar on } \\
\text { Marketing of Fashion, in São Paulo }\end{array}$ \\
\hline \multirow{8}{*}{$\begin{array}{c}\text { 2008-2010 } \\
\text { Juca Ferreira }\end{array}$} & \multirow[t]{2}{*}{2008} & National & $\begin{array}{l}\text { FIRJAN research: Mapping of the Creative Industry in } \\
\text { Brazil }\end{array}$ \\
\hline & & National & $2^{\text {nd }}$ edition of the Jogos BR public notice \\
\hline & \multirow{6}{*}{2010} & $\begin{array}{l}\text { State-Rio de } \\
\text { Janeiro }\end{array}$ & $\begin{array}{l}\text { Launching of the program Rio Criativo support platform } \\
\text { to the creative economy }\end{array}$ \\
\hline & & Municipal Recife & Foundation of Portomídia \\
\hline & & National & Launching of the National Culture Plan \\
\hline & & National & I National Fashion Seminar \\
\hline & & National & Creation of the Moda Brasil System (MDIC) \\
\hline & & National & Foundation of the ACIGAMES \\
\hline \multirow{5}{*}{$\begin{array}{l}\text { 2011-2012 } \\
\text { Ana de Hollanda }\end{array}$} & 2011 & $\begin{array}{l}\text { Municipal-São } \\
\text { Paulo }\end{array}$ & Study-Creative Economy in the city of São Paulo \\
\hline & 2011 & National & Inclusion of the digital games in the Rouanet law \\
\hline & 2012 & National & $\begin{array}{l}\text { Creation of the Secretariat of the Creative Economy } \\
\text { (SEC/MinC) }\end{array}$ \\
\hline & 2012 & National & $\begin{array}{l}\text { Publishing of the creative economy reference term of } \\
\text { SEBRAE }\end{array}$ \\
\hline & 2012 & National & "Economy and Culture of the Fashion in Brazil" (MinC) \\
\hline $\begin{array}{l}\text { 2012-2014 } \\
\text { Marta Suplicy }\end{array}$ & 2012 & National & Fashion designers eligible for the Rouanet law \\
\hline
\end{tabular}

